\title{
FOOD SUPER STORE SHOPPING ENVIRONMENT AND CONSUMER IMPULSIVE BUYING BEHAVIOR
}

\author{
\$a \\ MUQADDAS, Muhammad Fahid \\ AzFER, Syed Ali

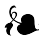 \\ National University of Modern Languages Islamabad \\ H-9 Islamabad, Pakistan \\ e-mail: mfahidm@gmail.com
}

\begin{abstract}
2
This study examines the impact of food super store shopping on impulsive buying behavior. The results highlight that discounted price, advertisement \&promotion, visual merchandising and emotional attachment, have impact on consumer impulsive buying behavior but special occasions and companion's influence donot impact consumer impulsive buying behavior. The study is based on a sample of food super store buyers from Rawalpindi and Islamabad. The exploration is useful for marketers to understand impulsive consumers and their choices. Food super stores are one of the growing businesses in Pakistan; therefore, this study will guide the marketers to understand this market segment effectively. The study also discovers the association between food super store shopping environment and types of consumer impulsive buying behavior which are cognitive impulsive buying and affective impulsive buying.
\end{abstract}

KEYWORDS: impulsive buying behavior, shopping environment, cognitive behavior, affective behavior

JEL Classification: M31, M37, M39

\section{INTRODUCTION}

Impulsive buying is usually defined as a consumer's unplanned purchase that is a significant element of consumer buying behavior. Consumer impulsive buying has improved the sales of food super stores and retailers. Impulsive consumer buying behavior is a widely recognized phenomenon. Impulsive buying accounts for up to $80 \%$ of all the purchases in certain product lines (ABRAHAMS, 1997).

According to Pakistan Economic Survey (2015-16), the per capita income was $\$ 1,560$. About 20\% growth was observed in per capita income over the last 5 years, the main growth in recent times showing a better well-being in spite of a slump in the economy that resulted in the more buying power of the middle class subsequently leading to more shopping which certainly justified the study on the impulsive buying behavior of consumer in food super stores. Many food super stores started their operation in Pakistan in this decade and are attracting a large number of consumers.

Major objective of the study are

- to identify the influence of food super store shopping environment on consumer impulsive buying behavior.

- to understand the influence of food super store shopping environment on both affective and cognitive impulsive buying behavior and

- to investigate the association among different factors of food super store shopping environment that could provide information to understand consumer buying behavior. 


\subsection{Research Question}

What is the impact of Food super store environment on consumer impulsive buying?

\subsection{Rationale of the Study}

The management of the food super stores tries to exploit consumer impulsive buying behavior, which is related to the fundamental requirement for instantaneous gratification. In this research paper, we are interested in finding relationship between variables regarding food super stores' environments with consumer impulse buying. This research paper will be useful for food super store management who want to improve their understanding regarding consumer impulsive buying behavior.

\subsection{Aim of the Study}

This paper aims to explore the relationship between various aspects of food super store shopping environment and consumer impulsive buying.

\subsection{Significance of the Study}

This research study will add rational to food super store shopping environment and consumer impulsive buying in Pakistan. It will facilitate marketers to satisfy the requirements of impulsive consumers as a particular target market. Hence this research is essential for the following reasons:

- A true understanding of consumer impulsive buying behavior could help store owners to attract the consumers with a better and convenient shopping environment.

- An understanding of the consumer impulsive buying behavior could help salespersons to sell food super store products in an effective manner.

- An improved understanding of the consumer impulsive buying behavior could assist advertisers to efficiently promote the different types of consumer impulses.

\subsection{Delimitations}

The results of this study cannot be generalized because it focuses only one segment of the market that is food super stores.

\subsection{Contributions}

Research has not yet been done to investigate the food super store environment on different types of consumer impulsive buying behavior.

\section{LITERATURE REVIEW}

Impulsiveness in buying is defined as making sudden, spontaneous, unintentional and carefree purchases (SPROLES and KENDALL, 1986). Impulsive buying is one of the key features of buying in all times and conditions. Unplanned buying prevails in all types of customers irrespective of their financial position and culture. High involvement purchases which are expensive and more time consuming are not made on impulses and apparently it has been seen that impulsive buying has an intention to give pleasure (VERPLANKEN and HERABADI, 2001). Further, impulsive buyers consider hedonic motives rather than a practical one as compared to non-impulsive buyers, and the impulsive buyer also tend to do shopping and purchases on their sensational will such as pleasure and excitement (VERPLANKEN and HERABADI, 2001). Pleasure is involved with the customer while doing impulsive buying; enough evidence has been found that consumer uses impulse buying to reduce their unpleasant and emotional mood (SILVERA, LAVACK and KROPP, 2008). In addition, sometimes people reward themselves by purchasing gifts for oneself in order to remove or lessen the negative psychological condition (MICK and DEMOSS, 1990). It is found that both negative and positive feelings have been related to impulsive buying (ROOK and GARDNE, 1993). Impulsive buying is a combination of affective and cognitive influence of individual, and it ultimately effects the decision making where affect refers to sentiments, emotions, way of thinking and frame of mind, on the other hand 
cognition refers to understanding, analyzing, judgment and interpreting information. The impulse buying trend may be defined with two facets of general impulsive buying behavior of customers: a) a cognitive aspect related to lack of planning for purchases and b) an effective aspect related to the feelings of pleasure and overwhelming desire to purchases (CACIOPPO and GARDNER, 2005). It has been seen that shopping environments are more effective in order to measure impulse buying (ROOK and GARDNE, 1993). It has also been observed that there is a constant difference in every individual's choice (i.e. vary from person to person) in relation to consumers' tendency for impulsive buying (DITTMAR and DRURY, 2000). Impulsive buying is a vast and diversified subject in the methodological and theoretical aspects, even it covers an area related to the instore shelf placement and space in between the shelves. The enjoyable, pleasant and attractive store shopping environment increases the chances of impulsive buying among consumers indirectly. As a store's pleasant and attractive environment keep the customer in store for a longer period of time so they can actively participate in price comparison and promotions thus it increases the chances of impulsive buying (TENDAI and CRISPEN, 2009).

\subsection{Cognitive Impulsive Buying}

Since impulsive buying varies with each individual, the personal satisfaction cannot be measured because it includes personal liking and disliking and the satisfaction is specifically linked to consumers lives e.g. family and job (DIENER et al., 1999). Cognitive behavior is a spontaneous urge to act without thinking and evaluating the results about to come in future and shows an unplanned buying behavior. Consumer purchases may be analyzed at cognitive level and during the decision making process the affective mood of customer influenced the decision (COLEY and BURGESS, 2003). It has been concluded from the findings that cognitive behavior of consumer plays an important role while making purchase decisions, however, its effect is smaller compared to that of the affective behavior (WEINBERG and GOTTWALD, 1982).

\subsection{Affective Impulsive Buying}

Although cognitive behavior seems to be logical and rational but it is inadequate to explain the buying behavior or purchasing decision of consumer in general (EREVELLES, 1998). Affective buying behavior is well demanding, convincing and persistent that it is near to impossible for the consumer to defy. Consumer self-esteem and gratitude motivates him/her to do impulsive buying in order to satisfy his/her feelings. Affection may be dealt as a primary source of consumer behavior (HIRSCHMAN and HOLBROOK, 1982). Negative affection in contrast of positive one is the motivating force behind chronic impulse buying. It may also influence the consumer behavior directly or indirectly by changing the cognitive behavior (CACIOPPO and GARDNER, 2005).

\subsection{Price and Discount}

Price conscious buyers always buy at discounted prices or at lowest price (SPROLES and KENDALL, 1986). Price is one of the most important factor in buying process. It really attracts the consumer to purchase and motivate them to buy as if their pocket allows to purchase. Discount on any product increases theimpulsiveness of the consumer and it compel or persuade the consumers to buy even if the prices are high. Consumer buying behavior is usually seen with a rationally comparative and informative search of product price and in this manner the consumers may take logical and balanced buying decisions. They buy the lowest price item if product substitute offers related benefits (JANISZEWSKI and LICHTENSTEIN, 1999). It has been found that prices will be an essential factor which open the choice for retail customers and is helpful in determining different customer groups (CARPENTER and MOORE, 2006). People show an elastic attitude towards the purchase of groceries in terms of fluctuation in prices. On the other hand prices proved to be the weakest factor of the consumer buying behavior of supermarket (FOX, MONTGOMERY and LODISH, 2004). However, there is controversy among the researchers about the influence of price of the products on buying behavior. Price has a great 
effect on the buying behavior of the consumer (SIROHI, MCLAUGHLIN and WITTINK, 1998).

\subsection{Advertising and Promotion}

Advertisement and promotion are major tools to market the product and to attract consumers to buy. It provokes the consumer impulsive buying behavior in manifold. Marketing managers are rapidly increasing their promotional budgets from the advertisement campaign outside the food super-store to in-store media advertising. Superstores have positively responded on emerging marketing tactics by enhancing careful shelf management and eye catching measures (MATTHEW and VOLLMER, 2008). It has been found that in-store advertisement can influence the consumer's unplanned buying behavior in two aspects, i.e. empirical (food super store environment effect) and informative (promotional effect). There is less emphasis on in-store product displays and more emphasis on elements that electrify the senses of buyers such as music, flat screen videos or graphics, lighting and flooring that tend to gain the brand image or character and help to generate an exclusive atmosphere and buying experience (MARSH, 1999).

\subsection{Visual Merchandising}

Visual merchandising is one of the important factors of impulse buying behavior (KERFOOT, DAVIS and WARD, 2003). Visual merchandising or display has been done in order to inform prospective customers about the product value and quality. The objective of the visual merchandising is to communicate the customer, to increase the store/company image and to promote multiple sales by attaching complementary items with products (FRINGS, 1999). Impulse buying behavior of a consumer is a reaction produced by being challenged the urge that intensify a want that eventually stimulate a consumer to make an unplanned buying decision. Visual merchandising provides shopping assistance, which may possibly be arising internal urge and subsequently creating an impulse buying (HAN et al., 1991). The food super store factors such as fixture, lightning, color scheme and visual merchandising have always been an immediate effect on consumer buying decision. Consumers sense the image of the store as a crucial element of buying because store appeal influences consumers to visit the same store (BAKER, LEVY and GREWAL, 1992).

\subsection{Emotional Attachment}

Impulsive buying behavior has been significantly influenced by sentiments, where emotion may enhance an individual motivation to react spontaneously without considering cognitive attitude (DONTHU and GILLILAND, 1996). Emotional status, with a diversified level between individuals, may have behavioral result in term of impulsive buying (COHEN and ANDRADE, 2004). It has been observed that there is a linkage among the emotion and behavior, where decision and behavior towards product may be influenced by the emotion, and found that the emotionattitude-behavior linkage may take place so rapidly or impulsively because of elasticity of risk averseness (RASHMI, 2001). It has been observed that when a consumer's emotion has been provoked while getting motivated, it may influence his/her buying decision. The emotional attachment has been considered instrumental in intensifying the impulsive buying (YEUNG and WYER, 2004). Some consumers are emotionally attached to a specific brand of product or store (SPROLES and KENDALL, 1986).

\subsection{Special Occasion}

In Pakistani society, we generally celebrate or commemorate special occasions or festivals with religious and national fervor. We spend heavy amounts in these occasions even more than our capacity and in these times impulsive buying have been observed at their peak (DEEPIKA and RAVI, 2011). The social needs on festivals cause more unintentional buying that leads to impulsive buying behavior (HAUSMAN, 2000). The buying power of consumers has increased hence the impulse purchasing of the products is also increasing exponentially mostly because of marketing strategies of stores during festivals (AHMED and VAYS, 2011). 


\subsection{Companion's Influence}

Generally, there are some contradictions as impulse buying might not be happened or buyers do not purchase more goods and intend to pay more while shopping with companions (NICHOLLS and LEATHERMAN, 1994). Buying decision may be affected by the influence of companion in both the aspects i.e. it may help to buy or argued not to buy the product. It has been observed that there may be positive or negative impact of social companion but in either case it shows significant result on impulse buying (BORGES, CHEBAT and BABIN, 2010).

\section{RESEARCH METHODOLOGY}

This research is based on quantitative data collected from the buyers of the food super stores from Islamabad and Rawalpindi.

\subsection{Proposed Theoretical Framework}

This research paper studies the impact of food super store shopping environment on the consumer impulsive buying behavior. The conceptual model of the research is shown in Figure 1.

\subsection{Hypotheses}

This research tests six hypotheses as described below:

$\mathrm{H}_{1}$ : Discounted price has a significant impact on consumer impulsive buying behavior.

$\mathrm{H}_{2}$ : Advertisement and promotion has a significant impact on consumer impulsive buying behavior.

Нз: Visual merchandising has a significant impact on consumer impulsive buying behavior.

H4: Emotional attachment has a significant impact on consumer impulsive buying behavior.

H5: Special occasion has a significant impact on consumer impulsive buying behavior.

H6: Companion influence has a significant impact on consumer impulsive buying behavior.

Super Store Shopping Environment

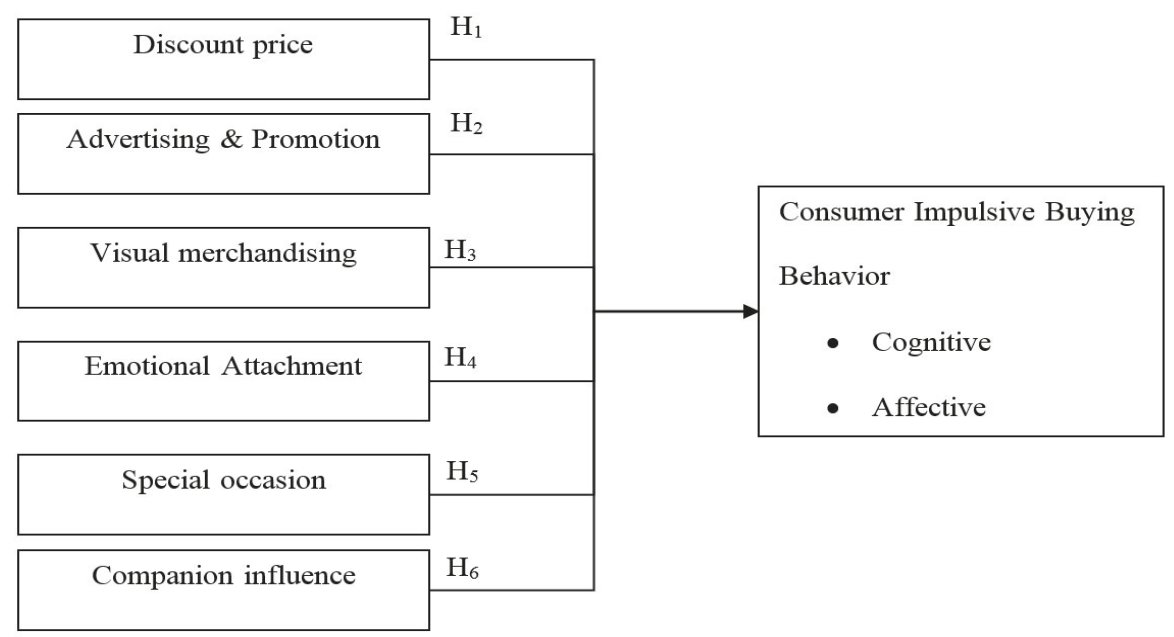

Conceptual Model of Impulsive Buying Behavior

FIG. 1

Source: Own elaboration 


\subsection{Research Design}

This is a quantitative research, conducted on the basis of primary data collected using an instrument adapted from Normative Influences on Impulsive Buying Behavior (ROOK and FISHER, 1995)and Individual Differences in Impulse Buying Tendency: Feeling and No Thinking (VERPLANKEN and HERABADI, 2001).

Population: The population of this research study is the buyers of food super store from Pakistan.

Sample: The questionnaire was floated to 325 buyers of food super stores from twin cities of Islamabad and Rawalpindi. Out of the 292 questionnaires received 27 were rejected due to incomplete information. Thus the response rate for this study was $81.54 \%$. Out of these 265 respondents 103were females (39\%) and 162 males (61\%).

Participants of study: Buyers of food super stores living in Islamabad and Rawalpindi participated in this research.

Instrument: The adapted questionnaire consists of 44 items to measure food super store shopping environment and consumer impulsive buying behavior. The questionnaire has 24 items to measure food super store shopping environment by discounted price, advertisement and promotion, visual merchandising, emotional attachment, special occasions, companion's influence and has 20 items to measure consumer impulsive buying behavior by cognitive impulsive buying behavior and affective impulsive buying behavior. The research instrument is based on five-point Likert scales ranging from 1 (strongly disagree) to 5 (strongly agree). The scale was reduced to 32 most important items with the help of factor analysis.

Data Collection: Self administrated questionnaire was distributed to the buyers of food stores namely Alfatah, Madina cash \& carry, Punjab cash \& carry etc. located in Rawalpindi \& Islamabad.

Data Analyses: The data was analyzed by SPSS. Linear regression and correlation were computed to explore relationship between factors.

\section{ReSULTS}

The skewness and kurtosis of all the constructs are presented in Table 1 and all the values are between -1 and +1 .

Skewness and Kurtosis

\begin{tabular}{lccccccc}
\hline & $\mathbf{1}$ & $\mathbf{2}$ & $\mathbf{3}$ & $\mathbf{4}$ & $\mathbf{5}$ & $\mathbf{6}$ & $\mathbf{7}$ \\
\hline Skewness & -0.665 & -0.501 & -0.628 & -0.546 & -0.522 & -0.528 & -0.393 \\
\cline { 2 - 8 } $\begin{array}{l}\text { Std. Error of Skewness } \\
\text { Kurtosis }\end{array}$ & 0.150 & 0.150 & 0.150 & 0.150 & 0.150 & 0.150 & 0.150 \\
\cline { 2 - 8 } & 0.891 & -0.172 & 0.766 & -0.086 & -0.333 & -0.069 & -0.256 \\
\cline { 2 - 8 } Std. Error of Kurtosis & 0.298 & 0.298 & 0.298 & 0.298 & 0.298 & 0.298 & 0.298 \\
\hline
\end{tabular}

Where 1=Discounted Price, 2=Advertisement \& Promotion, 3=Visual merchandising, 4=Emotional attachment, 5=Special occasion, $6=$ Companion's influence and $7=$ Impulsive buying behavior.

For factor extraction principal component analysis was used with Varimax (Kaiser Normalization). The resulted values of Cronbach Alpha and KMO are greater than 0.7 for all constructs, which shows the reliability of the data used and adequacy of the sample selected. The value of the Bartlett's test for all the constructs used was significant for $p<0.05$, thus confirming the sphericity of the data collected. 
Factor Analysis

\begin{tabular}{|c|c|c|c|c|c|c|c|}
\hline \multirow{2}{*}{\multicolumn{2}{|c|}{ Factors }} & \multicolumn{6}{|c|}{ Rotated Component Matrix (a) } \\
\hline & & $\mathbf{1}$ & 2 & 3 & 4 & 5 & 6 \\
\hline \multirow{4}{*}{ 1. =Discounted Price } & Special prices & 0.793 & & & & & \\
\hline & Attractive prices & 0.864 & & & & & \\
\hline & Various schemes & 0.860 & & & & & \\
\hline & Discounted products & 0.742 & & & & & \\
\hline \multirow{4}{*}{$\begin{array}{l}\text { 2.=Advertisement \& } \\
\text { Promotion }\end{array}$} & In store Advertisement & & 0.934 & & & & \\
\hline & promotional activities & & 0.832 & & & & \\
\hline & In store promotions & & 0.781 & & & & \\
\hline & Promotional event & & 0.793 & & & & \\
\hline \multirow{4}{*}{ 3.=Visual merchandising } & Attractive Display & & & 0.864 & & & \\
\hline & Attractive Packaging & & & 0.860 & & & \\
\hline & Product placement & & & 0.642 & & & \\
\hline & Complementary product & & & 0.934 & & & \\
\hline \multirow{4}{*}{ 4.=Emotional attachment } & Emotional attachment & & & & 0.832 & & \\
\hline & Best quality Products & & & & 0.684 & & \\
\hline & Recall value & & & & 0.768 & & \\
\hline & Bestselling products & & & & 0.703 & & \\
\hline \multirow{4}{*}{$5 \cdot=$ Special occasions } & Special occasions & & & & & 0.906 & \\
\hline & Requirement of product & & & & & 0.515 & \\
\hline & Traditions and customs & & & & & 0.791 & \\
\hline & Festival discounts & & & & & 0.678 & \\
\hline \multirow{4}{*}{ 6.=Companion's influence } & Shopping companion & & & & & & 0.701 \\
\hline & Companion help & & & & & & 0.660 \\
\hline & Companion Suggestion & & & & & & 0.734 \\
\hline & Companion pressure & & & & & & 0.690 \\
\hline Cronbach's Alpha & & 0.735 & 0.813 & 0.724 & 0.790 & 0.837 & 0.789 \\
\hline KMO & & 0.784 & 0.753 & 0.762 & 0.714 & 0.748 & 0.771 \\
\hline
\end{tabular}


The results of correlation analyses are presented in Table 3.

The food super store shopping environment (Table 4), as used in the model, has $54.1 \%$ impact (value of $\mathrm{R}^{2}$ ) on the consumer impulsive buying behavior.

The results of Table 5 shows the value of $\mathrm{F}=52.816(\mathrm{p}<0.001)$ that confirms the fitness of model used.

The coefficient of discounted price is 0.240 which shows $24 \%$ variation caused by the discounted price in consumer impulsive buying behavior using this model (Table 6). The $\mathrm{t}$ value for this coefficient is $4.159(\mathrm{p}<0.001)$ which is highly significant. This significance value leads us towards the acceptance of the first hypothesis. Hence discounted price has a significant impact on consumer impulsive buying behavior.

The coefficient of advertisement/promotion is 0.295 which shows $29.5 \%$ variation caused by the advertisement \& promotion in consumer impulsive buying behavior using this model. The $t$ value for this coefficient is 4.939 which is highly significant. This significance value leads us towards the acceptance of the second hypothesis. Hence advertisement and promotion has a significant impact on consumer impulsive buying behavior.

The coefficient of visual merchandising is 0.334 which reveals that there is $33.4 \%$ variation caused by the visual merchandising in consumer impulsive buying behavior. The $\mathrm{t}$ value for this coefficient is $5.379(\mathrm{p}<0.001)$ which is highly significant. The significant value guides us towards the acceptance of the third hypothesis. Hence visual merchandising has a significant impact on consumer impulsive buying behavior.

The coefficient for emotional attachment is 0.226 which reveals that there is $22.6 \%$ change caused by the emotional attachment in consumer impulsive buying behavior. The $t$ value for this coefficient is 5.072
( $p<0.001)$ which is extremely significant. This significance value leads us towards the acceptance of the fourth hypothesis. Hence emotional attachment has a significant impact on consumer impulsive buying behavior.

The coefficient of special occasions is 0.020which shows 2\% variation caused by the special occasions in consumer impulsive buying behavior using this model. The $t$ value for this coefficient is 0.350 which is not significant. This non significance value leads us towards the rejection of the fifth hypothesis. This confirms that special occasions have nonsignificant impact on consumer impulsive buying behavior.

The coefficient of companion's influence is 0.091 which shows $9.1 \%$ variation caused by the special occasions in consumer impulsive buying behavior using this model. The $t$ value for this coefficient is 1.387 which is not significant. This non significance value leads us towards the rejection of the sixth hypothesis. This confirms that companion's influence has non-significant impact on consumer impulsive buying behavior.

These results lead us to a conclusion that some of the food super store shopping environment factors discounted price, advertisement \& promotion, visual merchandising and emotional attachment have significant positive impact on consumer impulsive buying behavior. Furthermore, the results of this research revealed that the special occasions, companion's influence are not significant on consumer impulsive buying behavior. The research study also tells that visual merchandising is the most significant factor of food super store shopping environment for impulsive buying behavior.

The result of cognitive Impulsive buying behavior are discussed in Table 7. The food super store shopping environment, as used in the model (Table 7), has 23.4\% impact (value of $\mathrm{R}^{2}$ ) on the cognitive impulsive buying behavior. 


\section{Correlations}

\begin{tabular}{|c|c|c|c|c|c|c|c|}
\hline & 1. & 2. & 3. & 4. & 5. & 6. & 7 . \\
\hline 1. Discounted Price & 1 & & & & & & \\
\hline 2. Advertisement \& Promotion & 0.440 & 1 & & & & & \\
\hline 3. Visual merchandising & 0.721 & 0.522 & 1 & & & & \\
\hline 4. Emotional attachment & 0.265 & 0.607 & 0.373 & 1 & & & \\
\hline 5. Special occasions & 0.400 & 0.751 & 0.388 & 0.685 & 1 & & \\
\hline 6. Companion's influence & 0.523 & 0.760 & 0.638 & 0.646 & 0.747 & 1 & \\
\hline 7. Impulsive buying behavior & 0.598 & 0.413 & 0.661 & 0.492 & 0.429 & 0.563 & 1 \\
\hline
\end{tabular}

All correlation coefficients are significant at the o.o1 level (2-tailed).

Model Summary - Relationship between Food Super Store Shopping Environment and Consumer Impulsive Buying Behavior

\begin{tabular}{cccc}
\hline $\mathbf{R}$ & R Square & Adjusted R Square & Std. Error of the Estimate \\
\hline 0.742 (a) & 0.551 & 0.541 & 0.43544 \\
\hline
\end{tabular}

a Predictors: (Constant), Discounted Price, Advertisement \& Promotion, Visual merchandising, Emotional attachment, Special occasions, Companion's influence

b Dependent variable: impulsive buying behavior

TAB. 5

ANOVA

\begin{tabular}{lccccc}
\hline & Sum of Squares & df & Mean Square & F & Sig. \\
\hline Regression & 60.086 & 6 & 10.014 & 52.816 & $0.000(\mathrm{a})$ \\
\hline Residual & 48.919 & 258 & 0.190 & & \\
\hline Total & 109.006 & 264 & & & \\
\hline
\end{tabular}

a Predictors: (Constant), Discounted Price, Advertisement \& Promotion, Visual merchandising, Emotional attachment, Special occasions, Companion's influence

b Dependent variable: impulsive buying behavior

TAB. 6

Coefficients

\begin{tabular}{llll}
\hline & B & t & Sig. \\
\hline (Constant) & 0.939 & 5.097 & 0.000 \\
\hline Discounted price & 0.240 & 4.159 & 0.000 \\
\hline Advertisement \& promotion & 0.295 & 4.939 & 0.000 \\
\hline Visual merchandising & 0.334 & 5.379 & 0.000 \\
\hline Emotional attachment & 0.226 & 5.072 & 0.000 \\
\hline Special occasions & 0.020 & 0.350 & 0.726 \\
\hline Companion's influence & 0.091 & 1.387 & 0.167 \\
\hline
\end{tabular}

Model Summary - Relationship between Food Super Store Shopping Environment and Cognitive Impulsive Buying Behavior

\begin{tabular}{cccc}
\hline $\mathbf{R}$ & R Square & Adjusted R Square & Std. Error of the Estimate \\
\hline $0.501(\mathrm{a})$ & 0.251 & 0.234 & 0.55882 \\
\hline
\end{tabular}

a Predictors: (Constant), Discounted Price, Advertisement \& Promotion, Visual merchandising, Emotional attachment, Special occasions, Companion's influence

b Dependent variable: cognitive impulsive buying 
ANOVA (b)

\begin{tabular}{lccccc}
\hline & Sum of Squares & df & Mean Square & F & Sig. \\
\hline Regression & 27.053 & 6 & 4.509 & 14.439 & 0.000(a) \\
\hline Residual & 80.569 & 258 & 0.312 & & \\
\hline Total & 107.623 & 264 & & & \\
\hline
\end{tabular}

a Predictors: (Constant), Discounted Price, Advertisement\& Promotion, Visual merchandising, Emotional attachment, Special occasions, Companion's influence

b Dependent Variable: Cognitive impulsive buying

TAB. 9

Coefficients (a)

\begin{tabular}{llll}
\hline & B & t & Sig. \\
\hline (Constant) & 2.093 & 8.847 & 0.000 \\
\hline Discounted price & 0.102 & 1.381 & 0.168 \\
\hline Advertisement/promotion & 0.164 & 2.405 & 0.017 \\
\hline Visual merchandising & 0.274 & 3.437 & 0.001 \\
\hline Emotional attachment & 0.159 & 2.778 & 0.006 \\
\hline Special occasions & 0.042 & 0.571 & 0.569 \\
\hline Companion's influence & 0.145 & 1.712 & 0.088 \\
\hline
\end{tabular}

Dependent Variable: Cognitive impulsive buying

TAB. 10

Model Summary - Relationship between Food Super Store Shopping Environment and Affective Impulsive Buying Behavior

\begin{tabular}{cccc}
\hline $\mathbf{R}$ & R Square & Adjusted R Square & Std. Error of the Estimate \\
\hline 0.807 (a) & 0.651 & 0.643 & 0.47817 \\
\hline
\end{tabular}

a Predictors: (Constant), Discounted Price, Advertisement \& Promotion, Visual merchandising, Emotional attachment, Special occasions, Companion's influence

b Dependent variable: Affective impulsive buying

TAB. 11

ANOVA

\begin{tabular}{lccccc}
\hline & Sum of Squares & df & Mean Square & F & Sig. \\
\hline Regression & 109.900 & 6 & 18.317 & 80.110 & $0.000(\mathrm{a})$ \\
\hline Residual & 58.991 & 258 & 0.229 & & \\
\hline Total & 168.891 & 264 & & & \\
\hline
\end{tabular}

a Predictors: (Constant), Discounted Price, Advertisement\& Promotion, Visual merchandising, Emotional attachment, Special occasions, Companion's influence b Dependent Variable: Affective impulsive buying

$b$ Dependent Variable: Affective impulsive buying

TAB. 12

Coefficients

\begin{tabular}{llll}
\hline & $\mathbf{B}$ & $\mathbf{t}$ & Sig. \\
\hline (Constant) & -0.214 & -1.057 & 0.292 \\
\hline Discounted price & 0.378 & 5.961 & 0.000 \\
\hline Advertisement/promotion & 0.116 & 2.995 & 0.007 \\
\hline Visual merchandising & 0.394 & 5.779 & 0.000 \\
\hline Emotional attachment & 0.294 & 5.991 & 0.000 \\
\hline Special occasions & 0.082 & 1.305 & 0.193 \\
\hline Companion's influence & 0.038 & 0.526 & 0.600 \\
\hline
\end{tabular}

Dependent Variable: Affective impulsive buying 
The results of Table 8 shows the value of $\mathrm{F}=14.439(\mathrm{p}<\mathrm{0.001})$ that confirms the model used is suitable.

Advertisement \& promotion, visual merchandising and emotional attachment have significant positive impact on cognitive impulsive buying behavior and discounted price, special occasions, companion's influence are not significant on cognitive impulsive buying behavior.

The result of affective Impulsive buying behavior are discussed here in Table 10. The food super store shopping environment, as used in the model, has $64.3 \%$ impact (value of R2) on the affective impulsive buying behavior.

The results of Table 11 shows the value of $\mathrm{F}=80.110(\mathrm{p}<0.001)$. The model used is suitable.

Discounted price, advertisement \& promotion, visual merchandising and emotional attachment have significant positive impact on affective impulsive buying behavior and special occasions and companion's influence are not significant on affective impulsive buying behavior.

The research accomplished so far shows the importance of different shopping environments on consumer impulsive buying behavior while this research paper has gone a step forward and the impact of food super store shopping environment on cognitive impulsive buying behavior and affective impulsive buying behavior has been confirmed.

\section{IMPLICATIONS}

The results of this research have implications for academicians and managers.

\subsection{Academic Implications}

Presently most of the foreign marketing models are taught to the marketing students at different universities of Pakistan. This model could provide an opportunity to the academia to use indigenous model prepared in Pakistan, which represents the association between the food super store shopping environment and consumer impulsive buying behavior and its types.

\subsection{Managerial Implications}

The marketers need for studying indigenous models for preparing the right strategies has been fulfilled with the help of this research paper.

- A marketing strategy may be formulated based on the relationship between shopping environment and impulsive buying behavior in Pakistani society.

- Marketers can also have an understanding about the precise factors of food super store shopping environment that appeal to cognitive and affective impulsive buyers.

- Marketers can understand the importance of the promotional strategy to address the needs of impulsive buyers.

- Marketers can understand the need of visual merchandising which is highly valued by the impulsive consumers.

\subsection{Limitations of the Study}

The results this study can be partially generalized because it focuses only on customers of few food super stores. This study has examined the consumer impulsive buying behavior as a general basis but it was not specific on any particular product line.

\subsection{Future Research Possibilities}

This research paper has opened up new possibilities for the researcher by exploring the relationship between the food super store environment and two types of consumer impulsive buying behaviors, i.e. cognitive and affective impulsive buying behavior. Further research could be conducted to explore the impact of demographics and psychographic elements on the consumer shopping styles. It is further suggested that the consumer impulsive buying behavior of Pakistani food super store buyers should be compared to consumer impulsive buying behavior under different factors of shopping environment. Impulsive buying behavior across certain specific product categories could be examined that may contribute to the knowledge about the consumers. 


\section{REFERENCES}

Abrahams, B.: It's All in the Mind. Journal of Marketing. 1997. 11 (3) 31-33.

Ahmed, T. - Vays, J. N.: The Impulse Buying Behavior of Consumes For The FMCG Products. Jodhpur. Australian Journal of Basic and Applied Sciences. 2011. 5 (11) 1704-1710.

Coley, A. - Burgess, B.: Gender Differences in Cognitive and Affective Impulse Buying. Journal of Fashion Marketing and Management. 2003. 7 (3) 25-37.

Baker, J. - Levy, M. - Grewal, D.: An Experimental Approach to Making Retail Store Environment Decisions. Journal of Retailing. 1992. 64 (4) 43-56.

Borges, A. - Chebat, J. C. - Babin, B. J.: Does a Companion Always Enhance Shopping Experience? Journal of Retailing and Consumer Services. 2010. 17 (1) 294-299.

Cacioppo, J. - Gardner, W. 1.: Emotions. Annual Review of Psychology. 2005. 50 (1) 191-214.

Carpenter, M. J. - Moore, M.: Consumer Demographics, Store Attributes, and Retail Format Choice in the US Grocery Market. International Journal of Retail \& Distribution Management. 2006. 34 (6) 434-452.

Cohen, J. B. - Andrade, E. B.: Affective Intuition and Task-contingent Affect Regulation. Journal of Consumer Research. 2004. 31 (1) 358-367.

Deepika, J. - Ravi, K.: Organized Retail in India - Drivers Facilitator and SWOT Analysis. Asian Journal of Management Research. 2011. 2 (1) 265-279.

Diener, E. - Suh, E. M. - Lucas, R. E. - Smith, H. L.: Subjective Well-Being: Three Decades of Progress. Psychological Bulletin. 1999. 125 (2) 276-302.

Dittmar, H. - Drury, J.: Self-image - Is it in the Bag? A Qualitative Comparison between "Ordinary" and "Excessive" Consumers. Journal of Economic Psychology. 2000. 21 (2) 109-142.
Donthu, N. - Gilliland, D.: The Infomercial Shopper. Journal of Advertising Research. 1996. 36 (1) 69-76.

Erevelles, S.: The Role of Affect in Marketing. Journal of Business Research. 1998. 42 (3) $199-215$.

Fox, E. J. - Montgomery, A. L. - Lodish, L. M.: Consumer Shopping and Spending Across Retail Formats. The Journal of Busines. 2004. 77 (2) 525-560.

Frings, G. S.: Fashion: From Concept to Customer. New Jersey, Prentice-Hall, 1999.

Han, Y. K. - Morgan, G. A. - Kotsiopulos, A. - Kang-Park, J.: Impulse Buying Behavior of Apparel Purchasers. Clothing and Textile Research Journal. 1991. 9 (1) 15-21.

Hausman, A.: A Multi-method Investigation of Consumer Motivations in Impulse Buying Behavior. Journal of Consumer Marketing. 2000. 17 (5) 403-419.

Hirschman, E. C. - Holbrook, B. M.: Hedonic Consumption: Emerging Concepts, Methods and Propositions. Journal of Marketing. 1982. 46 (2) 92101.

Janiszewski, C. - Lichtenstein, D. R.: A Range Theory Account of Price Perception. Journal of Consumer Research. 1999. 25 (1) 353-368.

Kerfoot, S. - Davis, B. - Ward, P.: Visual Merchandizing and the Creation of Discernible Retail Brands. International journal of Retail and Distribution Management. 2003. 31 (1) 143-152.

Marsh, H.: Pop Stars of the Retail World. Journal of Marketing. 1999. 23 (1) 20-31.

Matthew, E. - Vollmer, C.: Major Media in the Shopping Aisle. Strategy \& Business. 2008. 53 (4) 68-79.

Mick, D. - DeMoss, M.: To Me from Me: A Descriptive Phenomenology of Self-gifts. Advances in Consumer Research. 1990. 17 (1) 677-682.

Nicholls, R. J. - Leatherman, S. P.: The Implications of Accelerated Sea-level Rise and Devel Oping Countries: A Discussion. Journal of Coastal Research. 1994. 14 (1) 17-29. 
Rashmi, A.: Sometimes It Just Feels Right: The Differential Weighting of AffectConsistent and Affect-Inconsistent Product Information. Journal of Consumer Research. 2001. 28 (6) 1-17.

Rook, D. W. - Gardne, M. P.: In the Mood: Impulse Buying's Affecttive Antecedents. Research in Consumer Behaviour. 1993. 6 (1) $1-28$.

Rook, D. - Fisher, R. J.: Normative Influences on Impulsive Buying Behavior. Journal of Consumer Research. 1995. 22 (1) $305-317$.

Silvera, D. H. - Lavack, A. M. - Kropp, F.: Impulse Buying: The Role of Affect, Social Influence, and Subjective Wellbeing. Journal of Consumer Marketing. 2008. 25 (1) 23-33.

Sirohi, N. - McLaughlin, E. W. - Wittink, D. R.: Model of Consumer Perceptions and Store Loyalty Intentions for a Supermarket Retailer. Journal of Retailing. 1998. 74 (2) 223-255.
Sproles, G. B. - Kendall, E. L.: A Methodology for Profiling Consumers' Shopping Styles. Journal of Consumer Affairs. 1986. 20 (2) 267-278.

Tendai, M., - Crispen, C.: In-store Shopping Environment and Impulsive Buying. African Journal of Marketing Management. 2009. 1 (4) 102-108.

Vandecasteele, B., - Maggie, G.: Motivated Consumer Innovativeness: Concept measurement, and validation. International Journal of Research in Marketing. 2010. 27 (4) 308-318.

Verplanken, B. - Herabadi, A.: Individual Differences in Impulse Buying Tendency: Feeling and No Thinking. European Journal of personality. 2001. 15 (1) 71-83.

Weinberg, P., - Gottwald, W.: Impulsive Buying as a Result of Emotion. Journal of Business Research. 1982. 10 (1) 43-57.

Yeung, C. M. - Wyer, R. S.: Affect, Appraisal and Consumer Judgment. Journal of Consumer Research. 2004. 31 (1) $412-424$.

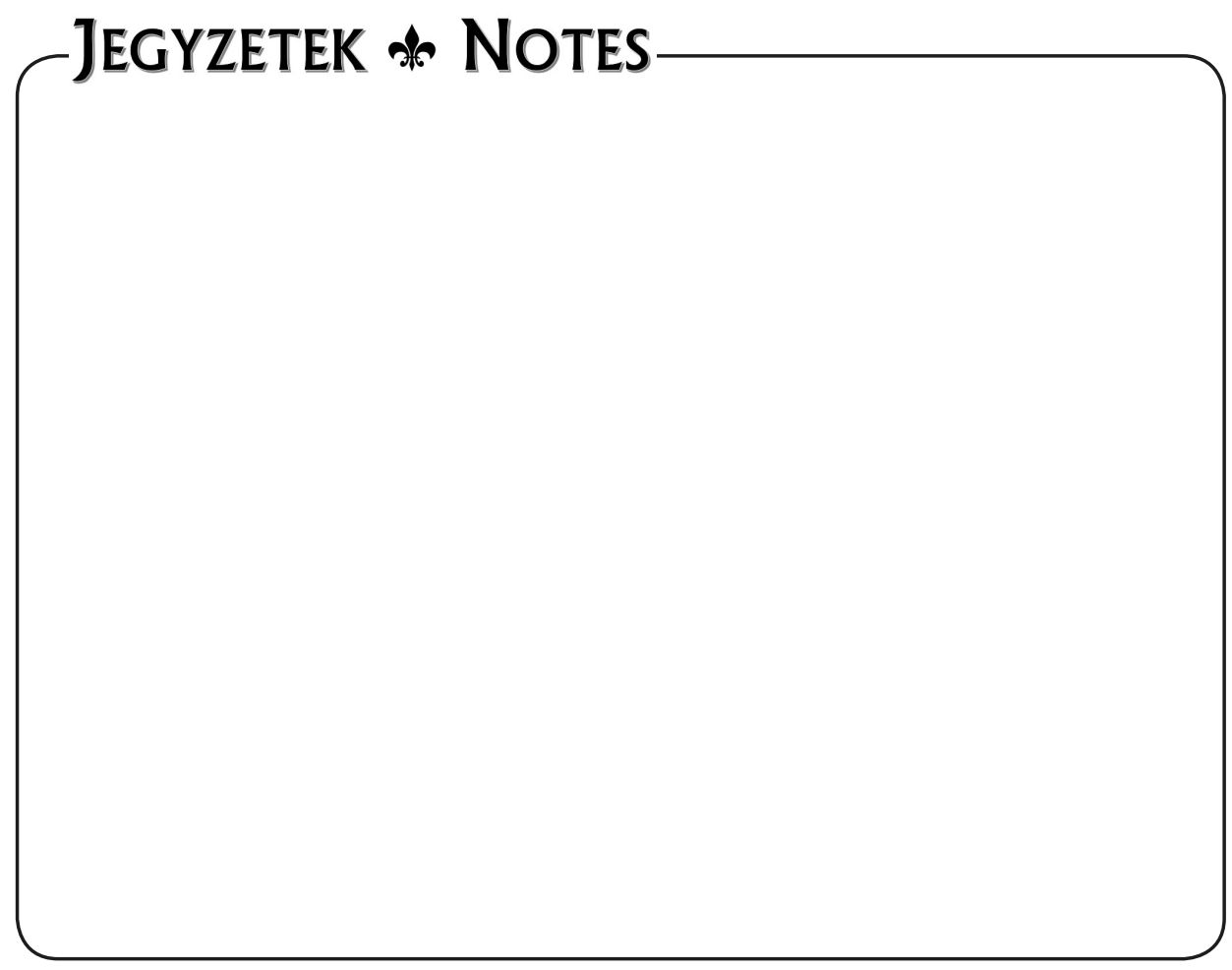




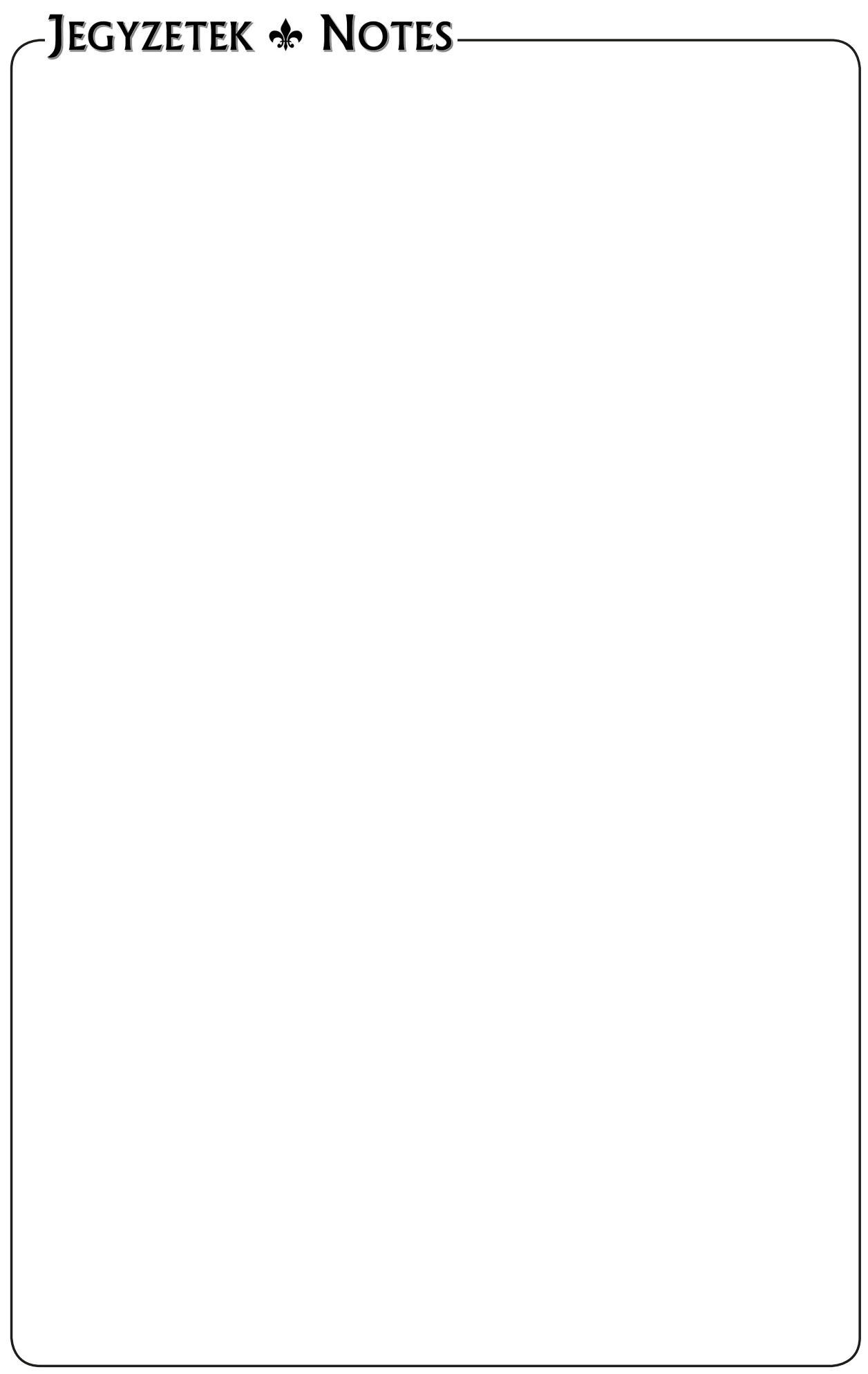

